\title{
Zaza Language
}

National Cancer Institute

\section{Source}

National Cancer Institute. Zaza Language. NCI Thesaurus. Code C154211.

An Indo-European language spoken primarily in eastern Turkey by the Zaza people. 